\title{
Library Services in Land-Grant Colleges Teaching Agriculture
}

Mr. Jones is pharmacy librarian, University of $W$ isconsin.

$T^{N}$ I950 a questionnaire was sent to 68 1 of the 70 land-grant colleges to determine the library services offered. ${ }^{1}$ The Massachusetts Institute of Technology and the School of Mines and Metallurgy of the University of Missouri do not maintain instruction in agriculture, and therefore were not included.

Of the 68 questionnaires sent, 55 were answered, representing a return of 80 per cent. Twenty-seven were from universities and 28 from colleges.

In the questionnaire, the services were divided according to: (a) orientation, (b) encouragement of reading, (c) courses of instruction, and (d) special services.

\section{Orientation}

According to the findings, most libraries did try to orient students to the library. Sixty-five per cent had handbooks, tours, lectures, films, exhibits and publications concerning the library.

Handbooks were prepared by over 70 per cent of the libraries. South Dakota State College mentioned distributing 500 handbooks, and North Carolina State College distributed 1000 a year.

Eighty per cent had tours to acquaint students with the library. The number varied from one to 46 a year. These were

${ }^{1}$ U.S. Department of Agriculture. Office of Experiment Stations. List of Land Grant Colleges in the U.S., November 1949. mentioned as a part of freshman week by six libraries. Washington State College had tours on the request of faculty members.

Lectures concerning the library and its use were given by 76 per cent of the libraries. These were given occasionally and were mentioned specifically for freshmen by two libraries. Thirteen lectures a year were given at Clemson College, South Carolina, on the use of the library.

Films on the arrangement of the library were used by Tennessee, Nebraska, and Wyoming universities, Prairie View A \& M College of Texas, Alcorn A \& M College, Mississippi, Colorado A \& M, Oklahoma A \& M and Maryland State College. The State College of Washington presented a film slide series with a prepared script "Approval to the library" in the freshman English classes in close cooperation with that department. It stressed the location of the library, reference tools and service points. Some follow-up was made by many of the instructors after the lecture. The script was read or a verbal commentary was given with the slides and a question-and-answer period was held at the conclusion of the lecture.

Library exhibits were arranged by about 73 per cent of the libraries. The number varied from one to 35 a year.

Seventy per cent of the libraries published, notices and articles concerning library resources and facilities in university publications. 


\section{Encouragement of Reading}

New books were displayed by 9I per cent of the libraries. These displays were continuous at Massachusetts University, Pennsylvania State College, Virginia Polytechnic Institute, Minnesota University, and New Mexico State College. Cornell displayed all new books for two weeks. Clemson College, Missouri University, Louisiana State and North Carolina University had new displays three times a year, while others had 40 or more.

Periodicals were displayed by 69 per cent of the libraries. Most of these were continuous, with the current issues being in the reading room.

Radio talks were given on books by II of the libraries (2O per cent). Utah State College had a radio series, and Colorado A \& $\mathrm{M}$ had radio talks weekly. At South Dakota State College they were given by the English department. Other schools giving radio talks about the library were: Illinois, Wisconsin, Mississippi, Michigan, Kentucky, Oregon and Iowa.

Lists of new books were sent to faculty members by 85 per cent of the libraries. The frequency varied greatly; however, most of them were sent monthly. Arkansas Agricultural library sent lists of new bulletins quarterly and the general library sent lists of new books.

Displays and bulletin boards on timely and interesting topics were used by 84 per cent. The number varied from three to over 50 a year, while others were continuous.

Duplicates were given or loaned to dormitories or infirmaries by 12 libraries. Rental collections were available at 13 per cent of the colleges.

Stacks were open to all patrons in 29 per cent of the libraries. This practice was most common where there was a separate agricultural library. Stacks were open only to graduate students and faculty in about 60 per cent of the schools. In some schools undergraduates could use the stacks by obtaining special permission. Clemson College and the University of Wisconsin had stacks open to all in the agricultural library, but not in the central library. Therefore, the actual percentage having stacks open throughout the library system was less than 30 per cent. Those who did indicate open stacks in both the agricultural and general section were the University of Alaska, Hawaii University and North Dakota State College. Oregon State preferred all open stacks, but this was not possible due to the arrangement of the building. They do have three divisional reading rooms for literature, science and engineering. They definitely felt the literature in these areas was more easily and effectively used than that in the closed stacks.

\section{Courses of Instruction}

Forty-five per cent of the schools gave instruction in the use of the library in an abridged course, usually in freshman English. At Clemson College, all English students spent one week on the use of the library. At Hawaii University it was given in all freshman English classes, and at Mississippi State all freshmen and transfer students were given library instruction. At North Carolina University, lessons were given by the English department using the library handbook. At Purdue University, one to three lectures were given in each course.

There were 18 per cent of the schools in this study which had a required course on the use of the library. At Maryland and New Hampshire Universities it was required only in some departments. Prairie View A \& M College, Texas, had a required course for all freshmen and new 
students. A few of the other schools requiring library instruction were: Utah, South Dakota, North Dakota and Iowa State Colleges.

An elective course on the use of the library was offered by $3 \mathrm{I}$ per cent of the schools, and 36 per cent gave some instruction to upper-classmen and graduate students. In some cases this consisted of a few lectures, while in other schools, such as Clemson College, classes were given one hour a week for a term to certain groups. In schools giving this instruction, it was often limited to a few departments.

Approximately 25 per cent of the schools gave no instruction in the use of the library.

\section{Special Services}

Only II libraries could supply both microfilm and photostat copies. There were 13 libraries that prepared microfilm and 19 which made photostats. In general, those having one service usually had the other.

Photostat and microfilm copies were ordered for patrons by 78 per cent of the libraries. Those not ordering them were mostly the smaller schools where less graduate work is done.

Most of the libraries secured and made interlibrary loans.

Reference collections for special classes were assembled by 65 per cent. Readers advisory service was, in general, given by staff members and most often done by the head librarian.

Telephone and messenger service was reported by 62 per cent in the study.

About 40 per cent of the libraries had audio-visual services, such as films, slides and recordings. Only 27 per cent had all three of these.

Periodicals were circulated by 69 per cent of the libraries, but this service was usually restricted to faculty members and graduate students.

\section{Conclusion}

The librarians in this study were aware of the importance of giving service. A number of libraries indicated their services would be increased when new buildings were ready. Others realized their services were inadequate but were hampered by a shortage of staff and facilities. Increased instruction in the use of the library appeared to be one of the greatest needs. This does not actually take more facilities, but would tend to increase the use of the library. With the increase in graduate work and the amount of literature available, librarians generally are agreed that this instruction is necessary.

This study also revealed the meager use of audio-visual materials and an expressed need for expansion in this area.

The sincere interest of present librarians in expansion of services promises a greater growth in library effectiveness in the near future.

\section{Drexel Offers Scholarships}

The School of Library Science, Drexel Institute of Technology, will grant three full tuition scholarships for the academic year 1952-53. The School offers a one-year curriculum leading to the degree of Master of Science in Library Science. These scholarships are awarded to graduates of approved colleges and universities who are American citizens. Applicants must have achieved high academic standing and be in need of financial aid.

Application should be made to the Dean of the School of Library Science, Drexel Institute of Technology, 32nd and Chestnut Streets, Philadelphia 4, Pennsylvania, before April I, 1952. Inquiries concerning scholarship aid to foreign students may also be addressed to the Dean. 